\title{
Two Years of Covid-19 in Retailing: Issues and Changes
}

\author{
Federica Caboni ${ }^{1} \&$ Lucia Pizzichini $^{2}$ \\ ${ }^{1}$ Department of Economic and Business Science, University of Cagliari, Italy \\ ${ }^{2}$ Department of Management, Faculty of Economics "G.Fuà", Polytechnic University of Marche, Italy \\ Correspondence: Federica Caboni, Department of Economic and Business Science, University of Cagliari, Italy. \\ E-mail: federica.caboni@unica.it
}

Received: September 30, 2021

doi:10.5539/ijbm.v16n12p76

\author{
Accepted: October 28, $2021 \quad$ Online Published: November 12, 2021 \\ URL: https://doi.org/10.5539/ijbm.v16n12p76
}

\begin{abstract}
During the COVID-19 pandemic, scholars have studied effects caused by the spread of the novel coronavirus in different fields such as management, finance, business, and social science in general. The retailing sector was profoundly affected by several modifications during and after the first and second waves of COVID-19 worldwide. The spread of Covid-19, with the associated restrictions, the fear of social contact and the need to maintain physical distance, influenced both consumers and retailers. However, it was found that there is a lack of studies on key issues in the retail sector. For that reason, this paper aims to study how scholars in the business management research field have analysed this new retailing crisis and the retail field's subsequent transformation. By adopting a qualitative research method based on a literature review, this paper identifies the main research topics - shopping, consumer behaviour, technology, and digitalization - related to COVID-19 and retailing in the business management research area. In particular, it was found that the above-mentioned topics need to be investigated in light of their connection and interrelation. The study shows the connection between the online shopping behaviours stimulated by the pandemic, the different retailer strategies to overcome the restrictions, and how digital technologies can serve as a bridge between the two.
\end{abstract}

Keywords: COVID-19, retail, consumer shopping behaviour, digitalization, online consumer behaviours, literature review

\section{Introduction}

The last two years (2020-2021) have been characterized by substantial changes linked to the worldwide spread of the novel coronavirus (Eger et al., 2021; Benvenuto et al., 2020). When the virus first appeared in China at the end of 2019 (Cowling et al., 2020; Riou \& Althaus, 2020), the global population did not know that people's lives worldwide would soon change, perhaps forever (Eger et al., 2021; Donthu and Gustafsoon, 2020; Laato et al., 2020; Pantano et al., 2020). Within a few months, the world was enveloped by a global pandemic (GordonWilson, 2021; Padhan \& Prabheesh, 2021), in which more than 210 million individuals have been infected (Worldometer, 2021). This pandemic has been characterized by the rapid spread of the virus, resulting in worldwide changes in social habits (Eger et al., 2021; Donthu \& Gustafsoon, 2020; Laato et al., 2020; Pantano et al., 2020) and consumption practices (Gordon-Wilson, 2021). All economic sectors have been affected by the spread of COVID-19 virus (Eger et al., 2021; Alon et al., 2020) and the retail sector is no exception. In particular, retailers of essential goods (Pantano et al., 2020) have seen increased profits, while retailers of non-essential goods have entered a severe crisis (Roggeveen \& Sethuraman, 2020; Pantano et al., 2020). This retail crisis immediately imposed the need to find new solutions to sell products even during the severe restrictions brought about by the spread of the virus, such as lockdown and quarantines (Wilder-Smith \& Freedman, 2020; Studdert \& Hall., 2020). The pandemic has in fact limited personal freedoms to an extent greater than any world event since the Second World War (Pantano et al., 2020). As a result, new consumer behaviours have arisen, with consumers abandoning their traditional purchasing habits to acquire new shopping skills with the help of modern technologies (Grewal et al., 2021), demonstrating a strong digital engagement (Jiang \& Stylos, 2021). Consumers have shown a new attachment to emerging technologies (Ukwuani \& Bashir, 2017), with specific focus on mobile applications, online shopping, home delivery services and smart working (Pantano et al., 2020; Roggeveen \& Sethuraman, 2020). Taking this scenario into consideration, this paper aims to study how scholars in the business management research field have approached this retailing crisis and the subsequent transformation (Roggeveen \& Sethuraman, 2020; Guthrie et al., 2021; Eger et al., 2021; Islam et al., 2021). 
Therefore, research questions leading the development of the paper are as follows:

RQ1: What are the main issues related to COVID-19 that have been analysed by scholars in the retailing sector? RQ2: How the COVID-19 pandemic changed the retail landscape?

These research questions help to lead the qualitative research through the adoption of a literature review to identified the main research topics related to COVID-19 and retailing addressed by the business management research field. Following this introduction, the paper continues with a methods and materials section that defines the three stages of research: collecting, selecting and analysing. Next, results on literature review are presented, following the two research questions, and main practical implications are suggested. Finally, a discussion and opportunities for further research conclude the paper.

\section{Method}

To address the two research questions, this paper uses a qualitative research. The literature review was conducted in three main stages to collect, select, and analyze 139 documents gathered from the Scopus database and updated in August 2021.

\subsection{Collecting Stage}

The first stage was developed by identifying how many documents have been published in the last two years $(2020=180$ documents; $2021=354$ documents $)$ using the following keywords: COVID-19 and retail. The keyword search in the Scopus database was set to include titles, abstracts, and keywords in order to retrieve all relevant publications edited in English. The Scopus database was selected by considering the high number of academic journals and documents included in this source. In fact, Scopus indexes 70 percent more sources than other databases, such as Web of Science (Brzezinski, 2015). From this first search 534 papers were obtained from several research areas, as shown in Figure 1. The main areas containing the majority of the papers related to retailing and COVID-19 were the business and management (13.4\%) and social science (13.3\%) research fields. Meanwhile, $16 \%$ of the papers were in other fields such as mathematics, psychology, arts and humanities, multidisciplinary, genetics and biology, physics and astronomy, nursing, earth and planetary science, health professions, and materials science.

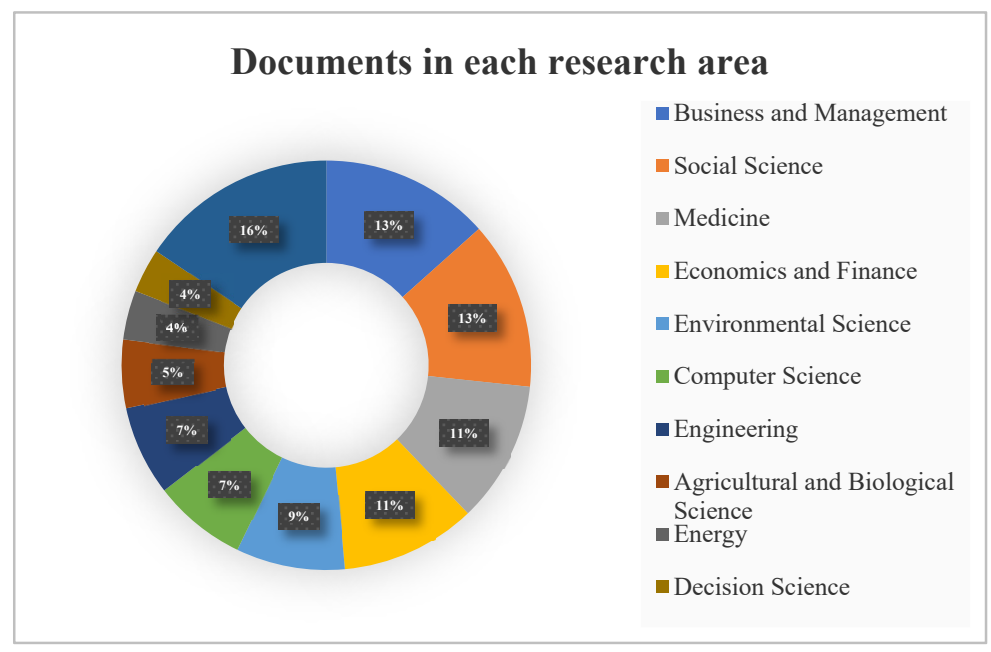

Figure 1. Documents' distribution in each research area

Source: Authors' data elaboration through Scopus Database.

\subsection{Selecting Stage}

The selection stage consists of selecting papers with a specific relation to retail and eliminating any documents not strictly related to this research area. In order to identify how many documents addressed the COVID-19 and retail themes, the business and management research area has been considered as it strongly connected with retail. It has been identified 139 documents published in the last two years $(2020=35 ; 2021=104)$ and have been selected documents (figure 2) published as research articles (88\%), conference paper (7\%), editorial study and note both as $2 \%$ and review for $1 \%$. The $88 \%$ of research articles were considered to identify the top journals in the business and management field published during the years 2020-2021 on COVID-19 and retail. The leading journals identified were: Journal of Retailing and Consumer Services; Journal of Business Research; Journal of 
Retailing; International Journal of Retail and Distribution Management; International Review of Retail, Distribution and Consumer Research; Technological Forecasting and Social Change; International Journal of Consumer Studies; and Innovative Marketing. Some other specific papers not strictly related to the retail sector were analyzed (but not included in the final count of 139 documents) in order to understand the rapid spread of the novel coronavirus and its consequences. Appropriate identification of research participants is critical to the science and practice of psychology, particularly for generalizing the findings, making comparisons across replications, and using the evidence in research syntheses and secondary data analyses. If humans participated in the study, report the eligibility and exclusion criteria, including any restrictions based on demographic characteristics.

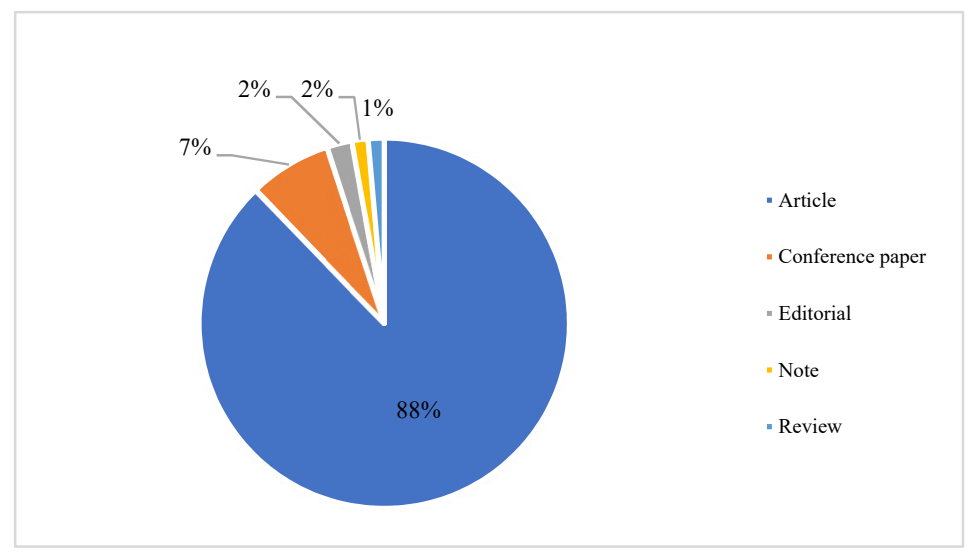

Figure 2. Document type

Source: Authors' data elaborated through Scopus database.

\subsection{Analyzing Stage}

A deep analysis of 139 documents collected in the business and management research field identified some specific issues that scholars worldwide have addressed during these last two years. Specifically, the following table 1 shows three main categories of these issues. Several issues identified were analyzed and categorized into three categories using a free word cloud generator, which made it possible to visualize frequently used terms such as shopping, consumer behavior, technology and digitalization. Moreover, the shopping category encompassed all the issues related to new shopping practices such as home consumption and home delivery, as well as retailers' strategies to survive this crisis. The category related to behaviour includes issues related to psychology, focusing on the fear of social contact and panic-related behaviour. The third category, called technology and digitalization, includes all the issues related to digitalisation and the usage of social media, electronic commerce, and mobile application during the pandemic.

Table 1. The main issues related to COVID-19 in the retailing sector

\begin{tabular}{lll}
\hline Shopping & Consumer Behaviour & Technology and digitalization \\
\hline Home food consumption & $\begin{array}{l}\text { Consumer's } \\
\text { psychology }\end{array}$ & Digitalization \\
Consumption practices & Panic buying & Social Media \\
Retailers' survival & Zero contact & E-commerce \\
New shopping practices & Panic behaviours & Online shopping \\
Home consumption & Purchasing intention & Mobile application \\
New engagement & Fear social contact & Digital engagement \\
Online order delivery & Fear new purchasing & Digital technology \\
Lockdown and quarantine & Social distancing & Touch technology \\
\hline
\end{tabular}

Source. Authors' data elaboration. 
In this phase, a further refinement of the sources was carried out to eliminate the papers that did not have a close connection with retail. Therefore 43 documents have been selected that correspond precisely to the search criteria adopted and inserted in the following tables (2-3-4). In addition to the author, these tables identify the journal they belong to and the article's primary focus.

\section{What are the Main Issues Related to COVID-19 in the Retailing Sector?}

The analysis of the papers identified three main research areas where scholars focused their attention: shopping, consumer behaviour, and technology and digitalisation. For each section, a selection of main scholarly contributions will be presented.

\subsection{Shopping}

During the rapid spread of COVID-19 (Benvenuto et al., 2020; Cowling et al., 2020; Riou and Althaus, 2020), people have experienced alternative ways of shopping (Eger et al., 2021; Gordon-Wilson, 2021; Fihartini et al., 2021; Donthu \& Gustafsoon, 2020; Laato et al., 2020; Pantano et al., 2020). The restrictions imposed by authorities worldwide (Guthrie et al., 2021; Pantano et al., 2020) forced people to change and enhance their shopping in different ways. More specifically, during the first wave (2020) of COVID-19, several countries (e.g. UK, Italy, Australia, China, Germany, Spain, France, Brazil, USA and others) faced lockdown, community containment, and mobility restrictions for extended periods of time (Laato et al., 2020; Wilder-Smith and Freedman, 2020). Due to these long-term situations, many people turned to online commerce (Fihartini et al., 2021; Grewal et al., 2021; Guthrie et al., 2021) and new home delivery services (Pantano et al., 2020; Roggeveen and Sethuraman, 2020; Yaprak et al., 2021) for their shopping needs, as well as to home gyms and smart-working (Wilder-Smith \& Freedman, 2020). Some research demonstrated people's increased appreciation, especially among those of the baby boomer generation (Parment, 2013), to use online shopping to satisfy their consumption needs (Eger et al., 2021). In fact, during the pandemic, several kinds of people discovered benefits from online services they had never used before, like home deliveries, store pick-up, and cashless payment (Pantano et al. 2020; Eger et al., 2021). Additionally, some scholars have focused their attention on home delivery services, identifying the interactions between the courier and the consumer as a problem during the pandemic, which could potentially be resolved through a drone delivery system (Grewal et al., 2021; Yaprak et al., 2021). Many retailers who sold online before COVID-19 saw their sales exponentially increase (Eger et al., 2021). Conversely, brick-and-mortar retailers who previously had no online presence had to adapt to survive (Gerwal et al., 2021) in the market during COVID-19. Specifically, many brick-and-mortar retailers had to develop new online strategies (Grewal et al., 2021), opening their stores in an online environment to stay in touch with their customers and maintain sales. In general, retailers' survival was one of the main challenges imposed by this virus. Some specific retail sectors have also found new ways to engage their customers. For example, fashion retailers organised online fashion shows to present new clothes and collections to buyers, influencers, and customers, thus accelerating their digital transformation (Silva \& Bonetti, 2021). Furthermore, strategies based on optimising the brand portfolio to minimise the overchoice effect while maximising the inventory turnover were developed as reasonable solutions during the COVID-19 pandemic (Sinha \& Sainy, 2021).

The pandemic also created problems for restaurants and cafes in cities, organising new services for their actual and potential customers by exploiting the potentiality of mobile food-ordering applications (Dirsehan \& Cankat, 2021). Food consumption at home became the primary choice for people during and after lockdown and quarantine. The fear of social contact and social distancing (Chang, 2021) let people experience home food consumption by using online food delivery services (Mehrolia et al., 2021). 
Table 2. Focus on shopping issues

\begin{tabular}{|c|c|c|c|}
\hline Authors & Year & Journal & Focus \\
\hline Pantano et al. & 2020 & Journal of Business Research & Consumption practices \\
\hline Roggeveen \& Sethuraman & 2020 & Journal of retailing & New shopping habits during COVID-19 \\
\hline Donthu \& Gustafsoon & 2021 & Journal of Business Research & Effects of COVID-19 on business \\
\hline Sinha \& Sainy & 2021 & $\begin{array}{l}\text { Journal of retailing and consumer } \\
\text { services }\end{array}$ & Small fashion retailers survival \\
\hline Dirsehan \& Cankat & 2021 & $\begin{array}{l}\text { Journal of retailing and consumer } \\
\text { services }\end{array}$ & $\begin{array}{l}\text { Role of mobile food-ordering applications } \\
\text { in developing restaurants brand } \\
\text { satisfaction and loyalty in the pandemic. }\end{array}$ \\
\hline Yaprak et al. & 2021 & $\begin{array}{l}\text { Technological forecasting and social } \\
\text { change }\end{array}$ & Online order delivery methods \\
\hline Fihartini et al. & 2021 & Innovative marketing & Online retail ethics \\
\hline Guthrie et al. & 2021 & $\begin{array}{l}\text { Journal of retailing and consumer } \\
\text { services }\end{array}$ & Online consumer resilience \\
\hline Eger et al. & 2021 & $\begin{array}{l}\text { Journal of retailing and consumer } \\
\text { services }\end{array}$ & Shopping attitudes during the pandemic \\
\hline Silva \& Bonetti & 2021 & $\begin{array}{l}\text { Journal of retailing and consumer } \\
\text { services }\end{array}$ & Digital Humans in fashion \\
\hline Grewal et al. & 2021 & Journal of retailing & $\begin{array}{l}\text { Enhancement of online shopping due to the } \\
\text { COVID-19 outbreak }\end{array}$ \\
\hline Gordon-Wilson & 2021 & $\begin{array}{l}\text { International Journal of consumer } \\
\text { studies }\end{array}$ & Consumption practices \\
\hline Mehrolia et al. & 2021 & $\begin{array}{l}\text { International Journal of consumer } \\
\text { studies }\end{array}$ & Online food delivery services \\
\hline
\end{tabular}

Source: Authors' data elaboration.

\subsection{Consumer Beehaviour}

During the spread of the novel coronavirus, people experienced different ways of shopping by modifying their purchasing behaviour as a result of the COVID-19 pandemic (Pantano et al., 2020; Grewal et al., 2021; Hartono et al., 2021; Zulauf et al., 2021). At the same time, consumers' experienced new feelings and sensations related to their purchasing intention and fear of COVID-19 (Pantano et al., 2020; Fihartini et al., 2021; Zulauf et al., 2021). Laato et al. (2020) showed that people who tried to avoid getting the virus through self-isolation engaged in more unusual unusual consumer behaviours and purchasing such as hoarding toilet paper. Regarding purchase intention, some scholars have shown and analysed how consumers have experienced fear related to spending their money on non-essential goods due to perceptions of scarcity and anxiety, in some cases developing forms of panic purchasing behaviour (Laato et al., 2020; Prentice et al., 2020; Omar et al., 2021). Moreover, feelings like fear of illness, fear of empty shelves, and fear of price increase increased the panic among consumers due to increasing impulse buying behaviour (Laato et al., 2020; Naeem, 2021). The panic emerged during the development of COVID-19 as a new normal consumer behaviour (Billore \& Anisimova, 2021). In particular, people engaged in such panic behaviour as a mechanism to prevent contagion from the virus through social contact (Billore \& Anisimova, 2021). At the same time, people demonstrated a compulsive attitude toward buying essential goods (Eger et al., 2021), specifically in the first wave of the virus during lockdown or quarantine. These new behaviours also increased with the fear of social contact (Chang, 2021), health risk (Fihartini et al., 2021), and the associated desire to experience shopping while avoiding interaction with others. Moreover, high satisfaction with online shopping showed that consumers are likely to continue to buy online during the COVID-19 pandemic (Kazancoglu \& Demir, 2021). One of the main consumer goals during the pandemic has been to preserve health and reduce the possibility of getting the virus by limiting contact with others (Park et al., 2021). Some studies have demonstrated (Fihartini et al., 2021) that the health risk was has been a more dominant influence on online shopping behaviour than other variables of online retail ethics. Other elements that have influenced shopping behaviours and, consequently, the intention to buy something during the pandemic are related to the perception of a chaotic and crowded store environment (Gupta \& Coskun, 2021), 
which negatively impacted purchase intent during the pandemic. Other studies have shown how the protective measures against the COVID-19 virus significantly and positively influenced consumers during their shopping process (Untaru \& Han, 2021). In particular, retailers' efforts to protect consumers' health contributed to increasing people's purchase intention (Untaru \& Han, 2021). All of these situations have had strong repercussions in the traditional ways of shopping. For that reason, several scholars have focused their attention on studying the new consumer psychology during COVID-19 by addressing the issues related to panic behaviours and panic buying (Prentice et al., 2020), purchasing intention and fear of new purchasing. Particularly during the pandemic, fear was the main factor that caused the increase in compulsive shopping by consumers worldwide (Eger et al., 2021).

Table 3. Focus on consumer behaviour issues

\begin{tabular}{|c|c|c|c|}
\hline Authors & Year & Journal & Focus \\
\hline Prentice et al. & 2020 & International Journal of Consumer studies & Panic Buying \\
\hline Pantano et al. & 2020 & Journal of Business research & Consumers' buying behavior in a time of emergency \\
\hline Chang & 2021 & Journal of retailing and consumer services & Social distancing in retail \\
\hline Omar et al. & 2021 & Journal of retailing and consumer services & $\begin{array}{l}\text { The panic buying behavior of consumers during the } \\
\text { pandemic }\end{array}$ \\
\hline Fihartini et al. & 2021 & Innovative marketing & $\begin{array}{l}\text { Consumer behavior within online shopping during the } \\
\text { pandemic }\end{array}$ \\
\hline Eger et al. & 2021 & Journal of retailing and consumer services & Fear appeal and the change in consumer behaviour \\
\hline Gupta \& Coskun & 2021 & Journal of retailing and consumer services & $\begin{array}{l}\text { The influence of human crowding and store messiness on } \\
\text { consumer purchase intention }\end{array}$ \\
\hline Untaru \& Han & 2021 & Journal of retailing and consumer services & Protective measures against COVID-19 \\
\hline Grewal et al. & 2021 & Journal of Retailing & $\begin{array}{l}\text { Changing in consumer behavior due to the COVID-19 } \\
\text { pandemic }\end{array}$ \\
\hline Naeem & 2021 & $\begin{array}{l}\text { International Journal of retail and distribution } \\
\text { management }\end{array}$ & $\begin{array}{l}\text { Customer psychology of impulse buying during COVID - } \\
19 \text { pandemic. }\end{array}$ \\
\hline Hartono et al. & 2021 & Global Business review & COVID-19 Pandemic and Adaptive Shopping Patterns \\
\hline Park et al. & 2021 & $\begin{array}{l}\text { Asia Pacific Journal of Marketing and } \\
\text { Logistics }\end{array}$ & Zero contact effect during COVID-19 Pandemic. \\
\hline Zulauf et al. & 2021 & $\begin{array}{l}\text { International review of retail, distribution and } \\
\text { consumer research }\end{array}$ & Buying behavior and risk perception \\
\hline $\begin{array}{l}\text { Kazancoglu } \\
\text { Demir }\end{array}$ & 2021 & $\begin{array}{l}\text { International Journal of retail and distribution } \\
\text { management }\end{array}$ & $\begin{array}{l}\text { Experience on repurchase intention in e-retailing during } \\
\text { COVID-19. }\end{array}$ \\
\hline $\begin{array}{l}\text { Billore } \\
\text { Anisimova }\end{array}$ & 2021 & International journal of consumer studies & Panic buying \\
\hline Laato et al. & 2020 & Journal of retailing and consumer services & $\begin{array}{l}\text { Unusual purchasing behavior during the early stages of the } \\
\text { COVID-19 pandemic }\end{array}$ \\
\hline
\end{tabular}

Source: Authors' data elaboration.

\subsection{Technology and Digitalization}

The advent of technology has transformed the world into a place without boundaries and walls (Beckers et al., 2021), partly by transforming the traditional retail landscape (Grewal et al., 2021; Shankar et al., 2021), which today comprises both physical and virtual elements. The digitalisation already affected retailing (Hagberg et al., 2016) before COVID-19. Furthermore, digital technologies such as IoT, AR, VR were already changing retailing (Grewal et al., 2021; Shankar et al., 2021; Caboni \& Hagberg, 2019; Hagberg et al., 2016) before this pandemic. However, this pandemic intensified the use of digital technologies (Grewal et al., 2021; Shankar et al., 2021) to support both consumers in their shopping experience and retailers to survive the various restrictions imposed by governments to contain the spread of the virus (Beckers et al., 2021; Laato et al., 2020; Pantano et al., 2020; Wilder-Smith and Freedman, 2020). For example, some studies (Silva \& Bonetti, 2021) show that the introduction of humans digital in the fashion sector can enhance the interaction between customers and retailers. Furthermore, the use of technologies such as robotics in stores (Grewal et al., 2021) has proved to be an ideal 
solution to shopping while socially distancing. In general, electronic commerce has been accompanied by physical commerce, but it has been replaced with traditional (Beckers et al., 2021). Consumers during the pandemic have used e-commerce to react to the pandemic and to attempt to reacquire a lost everyday life and adapting their shopping habits to the restrictions imposed by the government and by the spread of the virus (Guthrie et al., 2021). The intense use of e-commerce during the pandemic (Jafarzadeh et al. 2021; Guthrie et al., 2021) required high levels of professionalism on the part of retailers, both to manage the high flow of transactions in the delivery phases and to continue managing large volumes of business even after the pandemic (Beckers et al., 2021; Jafarzadeh et al. 2021). Due to the COVID-19 restrictions, people began to spend more time at home than before and consequently experienced the use of social media (Naeem, 2020; Naeem \& Ozuem, $2021)$ intensively. The use of social media thus strongly increased as a place where people could interact with other customers and chat with retailers (Naeem, 2020; Kwon et al., 2021), getting information and still conducting their everyday activities such as banking. In fact, due to social distancing, in-person banking operations have been replaced by home banking for routine transactions in several instances (Naeem \& Ozuem, 2021). At the same time, some retailers used social media to present new products, reserve discounts, offer home delivery, and other similar services. A new way of shopping was developed, led by digital engagement (Jiang \& Stylos, 2021) through digital technology. The use of smartphones increased during the pandemic, enhancing people's reliance on these devices (Anand et al., 2021). Mainly through smartphones, people have access to several kinds of mobile applications that are practical for saving time and, during the pandemic, ordering essential and non-essential goods while protecting themselves from COVID-19 (Dirsehan \&Cankat, 2021). Specifically, due to the coronavirus spread, mobile applications have attracted increasing attention as a source of unprecedented opportunity for retailers ( $\mathrm{Li} \&$ Fang, 2021). The lockdown also increased consumers' engagement in various pro-social or virtue-based activities using their smartphones (Anand et al., 2021). The use of innovative technologies such as touch technologies (Racat et al., 2021) could have a significant impact on the decision-making process. Some studies show (Racat et al., 2021) the importance of customers interacting with a touch interface to get specific information or pleasure through interaction with products in an online shopping environment.

Table 4. Focus on technology and digitalization issues

\begin{tabular}{|c|c|c|c|}
\hline Authors & Year & Journal & Focus \\
\hline Naeem & 2021 & Qualitative market research & Role of social media during COVID-19 pandemic \\
\hline Beckers et al. & 2021 & $\begin{array}{l}\text { Journal of retailing and consumer } \\
\text { services }\end{array}$ & E-commerce opportunities enhanced by the pandemic \\
\hline Anand et al. & 2021 & $\begin{array}{l}\text { Journal of retailing and consumer } \\
\text { services }\end{array}$ & $\begin{array}{l}\text { Smartphone reliance and engagement on social activities via } \\
\text { smartphones. }\end{array}$ \\
\hline $\begin{array}{l}\text { Jiang } \\
\text { Stylos }\end{array}$ & 2021 & $\begin{array}{l}\text { Technological forecasting and social } \\
\text { change }\end{array}$ & $\begin{array}{l}\text { Digital engagement and the role of digital technologies in transforming } \\
\text { the retail ecosystem during the COVID-19 pandemic. }\end{array}$ \\
\hline Racat et al. & 2021 & $\begin{array}{l}\text { Technological forecasting and social } \\
\text { change }\end{array}$ & Touch technologies for product evaluation and purchase intention \\
\hline Kwon et al. & 2021 & $\begin{array}{l}\text { Journal of retailing and consumer } \\
\text { services }\end{array}$ & $\begin{array}{l}\text { External pressure on small businesses to adopt or increase use of social } \\
\text { media }\end{array}$ \\
\hline $\begin{array}{l}\text { Jafarzadeh et } \\
\text { al. }\end{array}$ & 2021 & $\begin{array}{l}\text { Journal of retailing and consumer } \\
\text { services }\end{array}$ & Increased use of e-commerce and failure during delivery phase \\
\hline Li \& Fang & 2021 & $\begin{array}{l}\text { Electronic commerce research and } \\
\text { applications }\end{array}$ & Mobile application for retailers \\
\hline Guthrie et al. & 2021 & $\begin{array}{l}\text { Journal of retailing and consumer } \\
\text { services }\end{array}$ & E-commerce before during and after a COVID-19 lockdown \\
\hline $\begin{array}{l}\text { Naeem } \quad \& \\
\text { Ozuem }\end{array}$ & 2021 & $\begin{array}{l}\text { Journal of retailing and consumer } \\
\text { services }\end{array}$ & $\begin{array}{l}\text { The role of social media in internet banking transition during COVID-19 } \\
\text { pandemic }\end{array}$ \\
\hline $\begin{array}{l}\text { Silva } \\
\text { Bonetti }\end{array}$ & 2021 & $\begin{array}{l}\text { Journal of retailing and consumer } \\
\text { services }\end{array}$ & Digital humans in fashion \\
\hline Grewal et al. & 2021 & Journal of Retailing & Retailing in the new technology era \\
\hline Shankar et al. & 2021 & Journal of Retailing & Technology changing retail \\
\hline Naeem & 2021 & $\begin{array}{l}\text { International Journal of retail and } \\
\text { distribution management }\end{array}$ & Use of social media during the COVID-19 pandemic \\
\hline
\end{tabular}

Source: Authors' data elaboration. 


\section{Discussion}

\subsection{How the COVID-19 Pandemic is Changing the Retail Landscape?}

The analysis of the literature on Covid-19 and retail highlighted the following main themes of studies: shopping, technology and digitalization, and consumer behaviour. In particular, it was found that the above-mentioned topics need to be investigated in light of their connection and interrelation (Figure 3). The diffusion of the Covid-19 pandemic forced all countries in the world to adopt measures to contain the spread of the virus and improve the health protection of the population. On March 11, 2020, the World Health organization (WHO) declared COVID-19 a pandemic, and lockdown and quarantine measures were introduced (Guthrie et al., 2021). People was forced to stay home, and businesses were forced to stop operations, with consequences for consumer behaviour due to the fear of contagions on one side (Fihartini et al., 2021) and the governmental restrictions on the other (Guthrie et al., 2021; Pantano et al., 2020). Such restrictions were imposed to maintain social distancing, resulting in changes in consumers' needs and shopping habits. Especially in the first wave of the pandemic, consumers' needs were focused on buying essential goods in a compulsive way (Eger et al., 2021). Within the consumer behaviour field, the decision-making process has a relevant role, and, as stated by Pantano et al. (2020), it is influenced by different levels of risk aversion and perception. The health risk (Fihartini et al., 2021) and the fear of social contact (Chang, 2021), led consumers towards a "zero contact" (Park et al., 2021) shopping behaviour. Therefore, as in other stressful circumstances (Mathur et al. 2003; Guthrie et al., 2021) the consumption lifestyle changed, and physical interaction was limited in favor of digital interaction. Online consumption affected all different aspects of human life, from work to leisure activities (Wilder-Smith \& Freedman, 2020) and social life (Chang, 2021). Consumers discovered the benefit of online shopping and home delivery, which in many cases are more practical, cheaper, and avoid the stress imposed by regulations in retail outlets (Pantano et al., 2020; Eger et al., 2021; Guthrie et al., 2021). In particular, the safety of online shopping was one of the main aspects that led "late adopters" to buy online for the first time. As shown by Guthrie et al. (p. 3, 2021), usually older people are included in this category (Lv et al., 2019), having started to shop online for convenience and safety reason but showing a willingness to continue after the pandemic. The baby boomer generation in particular showed a greater orientation towards the adoption of new technologies and online shopping during the pandemic, which confirmed and increased their satisfaction with this type of purchase (Parment, 2013; Eger et al., 2021). People acquired new skills with online order delivery (Mehrolia et al., 2021) and new engagement with retailers, even with shops whose physical locations were closed but that were available for shopping via their online channels. Retailers, meanwhile, were affected differently by Covid-19 depending on the type of goods they were selling (Roggeveen \& Sethuraman 2020). Indeed, grocery and essential goods stores were the only types of physical stores allowed to be open throughout the pandemic; they raised sales but at the same time had to face challenges on their supply chain to deliver goods on time in the store and at home (Pantano et al., 2020; Grewal et al., 2021). The adoption of digital technologies helped them to improve services so as to facilitate consumers' decision making and purchasing process (Kim, 2020) and satisfy consumers' needs. Also, retailers of non-essential goods found benefits from the adoption of digital technologies. In particular, the online market allows them to reach people even more than before, all over the world. These changes have been aided and accelerated by the use and application of new technologies by both consumers and retailers (Beckers et al., 2021; Laato et al., 2020; Pantano et al., 2020; Wilder-Smith \& Freedman, 2020). Many innovative and technological ways of engaging customers and staying in touch have been exploited during the pandemic (Silva \& Bonetti, 2021; Sinha and Sainy, 2021). This emergency contributed to accelerating the adoption the use of social media by retailers that had to adapt quickly even though some, like small retailers, were not yet fully ready to do so (Kwon et al., 2021). The use of websites, social media and other technologies like augmented reality and virtual reality enhanced the interaction between customers and retailers (Naeem, 2020; Kwon et al., 2021; Grewal et al., 2021). During the pandemic, the use of smartphones and digital devices increased, stimulating digital engagement (Anand et al., 2021) and allowing retailers to maintain the same offers online as they had offline. At the same time, consumers could easily and quickly access information and complete their purchases. Digital technologies emerged more fully as the link between new online consumers' shopping behaviours and retailers' needs to overcome physical restrictions and be in contact with consumers. 


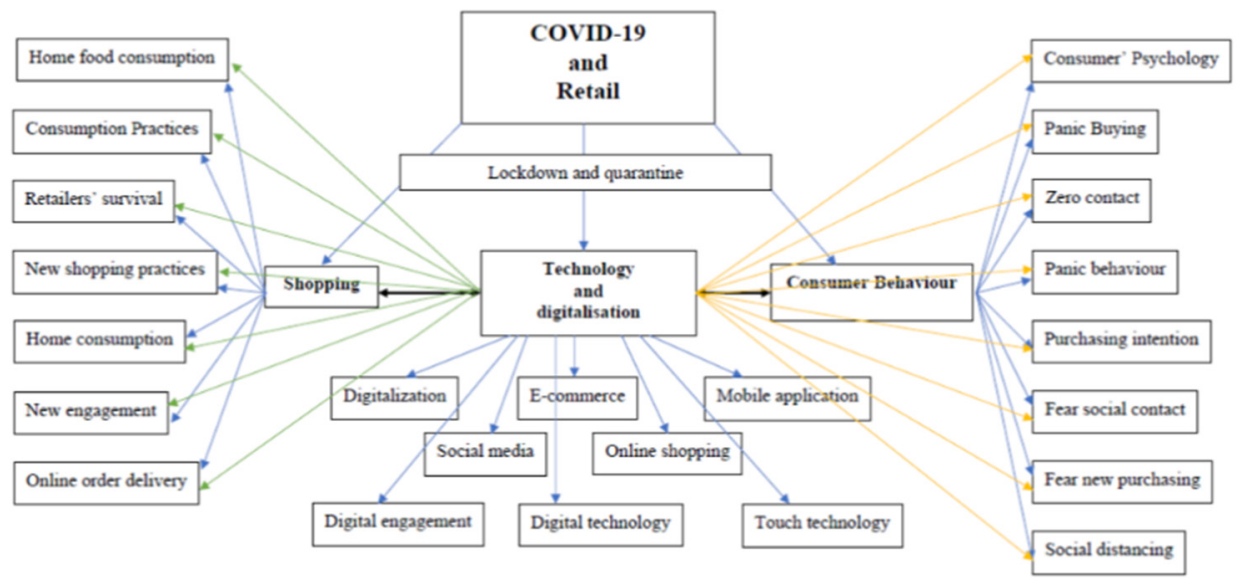

Figure 3. Conceptual map

Source. Authors' data elaboration.

\section{Conclusion and Practical Implications}

The review of the main contributions in the business and management research makes it possible to highlight some interesting practical implications. The study shows the connection between the online shopping behaviours stimulated by the pandemic, the different retailer strategies to overcome the restrictions, and how digital technologies can serve as a bridge between the two. Initially, retailers need to take into consideration that the pandemic has stimulated consumers' orientation towards technology adoption (Jiang \& Stylos, 2021); therefore, they need to deliver offers based on user-friendly digital tools according to different targets. Moreover, retailers need to adapt their business model to the changed attitudes and habits of consumers to satisfy expectations during the different steps of retail process (Jiang \& Stylos, 2021). The online consumer shopping behaviours could persist in the future in non-emergency conditions as well (Pantano et al., 2021); therefore, retailers should provide online offers even if the physical store will eventually return without any restrictions. Finally, the Covid-19 pandemic showed the importance of being digitally connected from both consumers' and businesses' side. Therefore, government can learn from this critical situation to develop strategies to implement digital infrastructures.

\section{Limitation and Further Research}

The principal limitation of this research is related to the limited period in which the papers were selected. More specifically, papers already written and those in press analyze the pandemic's effects on retail at the current stage. The long-term effects of the pandemic are still unknown, as the pandemic is still ongoing. An update of the literature on COVID-19 and retail will be proposed when the pandemic has fully ended. In this way, it will be possible to compare the effects of the pandemic and verify whether they continue to persist afterwards. Also, consumers may maintain habits that they adopted during the pandemic afterward (Pantano et al., 2021), and it would be interesting to investigate the reasons behind this, including what elements influence the decision and what the effects are.

\section{References}

Alon, T., Doepke, M., Olmstead-Rumsey, J., \& Tertilt, M. (2020). The impact of COVID-19 on gender equality. National Bureau of economic research (w26947).

Anand, A., Vessal, S. R., Rathi, K., \& Ameen, N. (2021). Show me your mobile and I will tell you who you are: Forecasting consumer compassion and altruism behaviour through smartphone type and usage. Journal of Retailing and Consumer Services 63, 102657. https://doi.org/10.1016/j.jretconser.2021.102657

Beckers, J., Weekx, S., Beutels, P., \& Verhetsel, A. (2021). COVID-19 and retail: The catalyst for e-commerce in Belgium? Journal of Retailing and Consumer Services, 62, 102645. https://doi.org/10.1016/j.jretconser.2021.102645

Benvenuto, D., Giovanetti, M., Ciccozzi, A., Spoto, S., Angeletti, S., \& Ciccozzi, M. (2020). The 2019-new coronavirus epidemic: evidence for virus evolution. Journal of medical virology, 92(4), 455-459. 
http://dx.doi.org/10.1002/jmv.25688

Billore, S., \& Anisimova, T. (2021). Panic buying research: A systematic literature review and future research agenda. International Journal of Consumer Studies, 45(4), 777. http://dx.doi.org/10.1111/ijcs.12669

Brzezinski, M. (2015). Power laws in citation distributions: evidence from Scopus. Scientometrics, 103(1), 213-22. http://dx.doi.org/10.1007/s11192-014-1524-z

Caboni, F., \& Hagberg, J. (2019). Augmented reality in retailing: a review of features, applications and value. International Journal of Retail \& Distribution Management, 47(11), 1125-1140. https://doi.org/10.1108/IJRDM-12-2018-0263

Chang, T. S. (2021). Social distancing in retail: Influence of perceived retail crowding and self-efficacy on employees' perceived risks. Journal of Retailing and Consumer Services, 62, 102613. https://doi.org/10.1016/j.jretconser.2021.102613

Cowling, B. J., Ali, S. T., Ng, T. W., Tsang, T. K., Li, J. C., Fong, M. W., \& Wu, J. T. (2020). Impact assessment of non-pharmaceutical interventions against coronavirus disease 2019 and influenza in Hong Kong: an observational study. The Lancet Public Health, 5(5), 279-288. https://doi.org/10.1016/S2468-2667(20)30090-6

Donthu, N., \& Gustafsson, A. (2020). Effects of COVID-19 on business and research. Journal of Business Research, 117(1), 284-289. https://doi.org/10.1016/j.jbusres.2020.06.008

Eger, L., Komárková, L., Egerová, D., \& Mičík, M. (2021). The effect of COVID-19 on consumer shopping behaviour: Generational cohort perspective. Journal of Retailing and Consumer Services, 61, 102542. https://doi.org/10.1016/j.jretconser.2021.102542

Fihartini, Y., Helmi, R. A., Hassan, M., \& Oesman, Y. M. (2021). Perceived health risk, online retail ethics, and consumer behavior within online shopping during the COVID-19 pandemic. Innovative Marketing, 17(3), 17-29. http://dx.doi.org/10.21511/im.17(3).2021.02

Gordon-Wilson, S. (2021). Consumption practices during the COVID-19 crisis. International Journal of Consumer Studies. http://dx.doi.org/10.1111/ijcs.12701

Gordon-Wilson, S. (2021). Consumption practices during the COVID-19 crisis. International Journal of Consumer Studies. https://doi.org/10.1111/ijcs.12701

Grewal, D., Gauri, D. K., Roggeveen, A. L., \& Sethuraman, R. (2021). Strategizing Retailing in the New Technology Era. Journal of Retailing, 97(1), 6-12.

Gupta, S., \& Coskun, M. (2021). The influence of human crowding and store messiness on consumer purchase intention-the role of contamination and scarcity perceptions. Journal of Retailing and Consumer Services 61, 102511. https://doi.org/10.1016/j.jretai.2021.02.004

Guthrie, C., Fosso-Wamba, S., \& Arnaud, J. B. (2021). Online consumer resilience during a pandemic: An exploratory study of e-commerce behavior before, during and after a COVID-19 lockdown. Journal of Retailing and Consumer Services, 61, 102570. https://doi.org/10.1016/j.jretconser.2021.102570

Hagberg, J., Sundstrom, M., \& Egels-Zandén, N. (2016). The digitalization of retailing: an exploratory framework. International Journal of Retail \& Distribution Management, 44(7), 694-712. https://doi.org/10.1108/IJRDM-09-2015-0140

Hartono, A., Ishak, A. I., Abdurrahman, A., Astuti, B., Marsasi, E. G., Ridanasti, E., ... \& Muhammad, S. (2021). COVID-19 Pandemic and Adaptive Shopping Patterns: An Insight from Indonesian Consumers. Global Business Review. http://dx.doi.org/10.1177/09721509211013512

Islam, T., Pitafi, A. H., Arya, V., Wang, Y., Akhtar, N., Mubarik, S., \& Xiaobei, L. (2021). Panic buying in the COVID-19 pandemic: A multi-country examination. Journal of Retailing and Consumer Services, 59, 102357. https://doi.org/10.1016/j.jretconser.2020.102357

Jafarzadeh, H., Tafti, M., Intezari, A., \& Sohrabi, B. (2021). All's well that ends well: Effective recovery from failures during the delivery phase of e-retailing process. Journal of Retailing and Consumer Services, 62, 102602. https://doi.org/10.1016/j.jretconser.2021.102602

Jiang, Y., \& Stylos, N. (2021). Triggers of consumers' enhanced digital engagement and the role of digital technologies in transforming the retail ecosystem during COVID-19 pandemic. Technological Forecasting and Social Change 172, 121029. https://doi.org/10.1016/j.techfore.2021.121029 
Kazancoglu, I., \& Demir, B. (2021). Analysing flow experience on repurchase intention in e-retailing during COVID-19. International Journal of Retail \& Distribution Management. https://doi.org/10.1108/IJRDM-10-2020-0429

Kwon, W. S., Woo, H., Sadachar, A., \& Huang, X. (2021). External pressure or internal culture? An innovation diffusion theory account of small retail businesses' social media use. Journal of Retailing and Consumer Services, 62, 102616. https://doi.org/10.1016/j.jretconser.2021.102616

Laato, S., Islam, A. N., Farooq, A., \& Dhir, A. (2020). Unusual purchasing behavior during the early stages of the COVID-19 pandemic: The stimulus-organism-response approach. Journal of Retailing and Consumer Services, 57, 102224. https://doi.org/10.1016/j.jretconser.2020.102224

Laato, S., Islam, A. N., Farooq, A., \& Dhir, A. (2020). Unusual purchasing behavior during the early stages of the COVID-19 pandemic: The stimulus-organism-response approach. Journal of Retailing and Consumer Services, 57, 102224. http://dx.doi.org/10.1016/j.jretconser.2020.102224

Li, C. Y., \& Fang, Y. H. (2021). Toward better purchase decision-performance: Linking person-environment fit to explorative and exploitative use of branded applications. Electronic Commerce Research and Applications, 48, 101063. http://dx.doi.org/10.1016/j.elerap.2021.101063

Lv, J., Wu, H., Qiang, Y., \& Liu, J. (2019). Research on intelligent assistant diagnosis method of CT image for lung nodule based on mobile computing. International Journal of Wireless and Mobile Computing, 17(3), 274-284. http://dx.doi.org/10.1504/IJWMC.2019.102268

Mathur, A., Moschis, G. P., \& Lee, E. (2003). Life events and brand preference changes. Journal of Consumer Behaviour: An international research review, 3(2), 129-141. https://doi.org/10.1002/cb.128

Mehrolia, S., Alagarsamy, S., \& Solaikutty, V. M. (2021). Customers response to online food delivery services during COVID-19 outbreak using binary logistic regression. International Journal of Consumer Studies 45(3), 1-13. https://doi.org/10.1111/ijcs.12630

Naeem, M. (2021). The role of social media to generate social proof as engaged society for stockpiling behaviour of customers during Covid-19 pandemic. Qualitative Market Research, 24(3), 281-301. https://doi.org/10.1108/QMR-04-2020-0050

Naeem, M. (2021). Understanding the customer psychology of impulse buying during COVID-19 pandemic: implications for retailers, International Journal of Retail \& Distribution Management, 49(3), 377-393. https://doi.org/10.1108/IJRDM-08-2020-0317

Naeem, M., \& Ozuem, W. (2021). The role of social media in internet banking transition during COVID-19 pandemic: Using multiple methods and sources in qualitative research. Journal of Retailing and Consumer Services, 60, 102483. http://dx.doi.org/10.1016/j.jretconser.2021.102483

Padhan, R., \& Prabheesh, K. P. (2021). The economics of COVID-19 pandemic: A survey. Economic Analysis and Policy, 70, 220-237. http://dx.doi.org/10.1016/j.eap.2021.02.012

Pantano, E., Pizzi, G., Scarpi, D., \& Dennis, Ch. (2020). Competing during a pandemic? Retailers' ups and downs during the COVID19 outbreak. Journal of Business Research, 116, 209-213. http://dx.doi.org/10.1016/j.jbusres.2020.05.036

Pantano, E., Priporas, C. V., Devereux, L., \& Pizzi, G. (2021). Tweets to escape: Intercultural differences in consumer expectations and risk behavior during the COVID-19 lockdown in three European countries. Journal of Business Research, 130, 59-69. http://dx.doi.org/10.1016/j.jbusres.2021.03.015

Park, A., An, H. S., Song, J. M., \& Chung, C. (2021). Please do not disturb: the effect of Zero-Contact Marketing on Korean consumers' decision-making process, Asia Pacific Journal of Marketing and Logistics. https://doi.org/10.1108/APJML-09-2020-0641

Parment, A. (2013). Generation Y vs. Baby Boomers: Shopping behavior, buyer involvement and implications for retailing. Journal of Retailing and Consumer Services, 20(2), 189-199. http://dx.doi.org/10.1016/j.jretconser.2012.12.001

Prentice, C., Quach, S., \& Thaichon, P. (2020). Antecedents and consequences of panic buying: The case of COVID-19. International Journal of Consumer Studies. https://doi.org/10.1111/ijcs.12649

Racat, M., Capelli, S., \& Lichy, J. (2021). New insights into 'technologies of touch': Information processing in product evaluation and purchase intention. Technological Forecasting and Social Change, 170, 120900. http://dx.doi.org/10.1016/j.techfore.2021.120900 
Riou, J., \& Althaus, C. L. (2020). Pattern of early human-to-human transmission of Wuhan 2019 novel coronavirus (2019-nCoV), December 2019 to January 2020. Eurosurveillance, 25(4), 2000058. https://doi.org/10.2807/1560-7917

Roggeveen, A. L., \& Sethuraman, R. (2020). How the COVID Pandemic May Change the World of Retailing. Journal of Retailing, 96(2), 169-171. http://dx.doi.org/10.1016/j.jretai.2020.04.002

Shankar, V., Kalyanam, K., Setia, P., Golmohammadi, A., Tirunillai, S., Douglass, T., ... \& Waddoups, R. (2021). How technology is changing retail. Journal of Retailing, 97(1), 13-27.

Silva, E. S., \& Bonetti, F. (2021). Digital humans in fashion: Will consumers interact? Journal of Retailing and Consumer Services, 60, 102430. http://dx.doi.org/10.1016/j.jretconser.2020.102430

Studdert, D. M., \& Hall, M. A. (2020). Disease control, civil liberties, and mass testing-calibrating restrictions during the COVID-19 pandemic, New England Journal of Medicine, 383(2), 102-104. http://dx.doi.org/10.1056/NEJMp2007637

Ukwuani, N., \& Bashir, E. (2017). Emerging technologies: an exploration of novel interactive technologies. International Journal of Information Systems in the Service Sectors, 9(4), 30-43. http://dx.doi.org/10.4018/IJISSS.2017100103

Untaru, E. N., \& Han, H. (2021). Protective measures against COVID-19 and the business strategies of the retail enterprises: Differences in gender, age, education, and income among shoppers. Journal of Retailing and Consumer Services, 60, 102446. http://dx.doi.org/10.1016/j.jretconser.2021.102446

Wilder-Smith, A., \& Freedman, D. O. (2020). Isolation, quarantine, social distancing and community containment: pivotal role for old-style public health measures in the novel coronavirus (2019-nCoV) outbreak, Journal of travel medicine, 27(2). http://dx.doi.org/10.1093/jtm/taaa020

Worldometer. (2021). COVID-19 coronavirus pandemic. Retrieved from https://www.worldometers.info/coronavirus/?ISCI $=030202$

Yaprak, Ü., Kılıç, F., \& Okumuş, A. (2021). Is the Covid-19 pandemic strong enough to change the online order delivery methods? Changes in the relationship between attitude and behavior towards order delivery by drone. Technological Forecasting and Social Change, 169, 120829. https://doi.org/10.1016/j.techfore.2021.120829

Zulauf, K., Cechella, F. S., \& Wagner, R. (2021). The bidirectionality of buying behavior and risk perception: an exploratory study. The International Review of Retail, Distribution and Consumer Research, 1-25. http://dx.doi.org/10.1080/09593969.2021.1936596

\section{Copyrights}

Copyright for this article is retained by the author(s), with first publication rights granted to the journal.

This is an open-access article distributed under the terms and conditions of the Creative Commons Attribution license (http://creativecommons.org/licenses/by/4.0/). 